\title{
The investigation of the relation between job involvement and organizational commitment
}

\author{
Mohammad Javad Esfahani ${ }^{a^{*}}$, Mostafa Emami ${ }^{b}$ and Hamid Reza Tajnesaei ${ }^{c}$
}

${ }^{a}$ Department of Industrial Engineering, Young Researchers Club, Naragh Branch, Islamic Azad University, Naragh, Iran

${ }^{b}$ Young Researchers Club, Kermanshah Branch, Islamic Azad University, Kermanshah, Iran

${ }^{c}$ Department of Management, Sanandaj Branch, Islamic Azad University, Sanandaj, Iran

C H R O N I C L E

Article history:

Received September 18, 2012

Received in revised format

21 December 2012

Accepted 21 December 2012

Available online

December 222012

Keywords:

Job involvement

Organizational commitment

Iran automaker industry

\section{A B S T R A C T}

This paper investigates the relationship between job involvement and organizational commitment among lower-level employees in Iranian automaker industry. In this study, job involvement is an independent variable, organizational commitment is dependent variable, and the analysis is performed using 100 randomly selected data through a questionnaire, which consists of four-parts. The study gathers biographical and occupational data using a selfdesigned 40-item questionnaire. The survey measures job involvement using Kanungo's 10item 5-point rating scale and organizational commitment is measured based on Mowday's 15item 5-point scale. The study uses different statistical techniques including Pearson Product Moment Correlation Technique and Multiple Regression Analysis. The results indicate that job involvement is strongly associated with organizational commitment. The paper therefore suggests that managers must put in all their efforts to promote job involvement in their companies.

\section{Introduction}

During the past few years, there have been enormous evidences recommending that organizational commitment could possibly lead to organizational success and efficiency (Mowday et al., 1982; Robbins, 2005). Organizational commitment plays an important role for management of organizations and learns more on what variables are useful for organizational commitment. Knowledge enables managers to build necessary conditions, which are conducive to the development of such antecedents of organizational commitment in their organizations. Organizational commitment can be described as employees' psychological attachments to the organization (Organisational Commitment Wikipedia, 2008) and it is possible to compute it through different factors including organizational objectives, the desire to belong to the organization and the willingness to display effort on behalf of the organization.

*Corresponding author. Tel: +9891876 54910

E-mail addresses: mohammadjavadesfahani@gmail.com (M. J. Esfahani) 
Maxwell and Steele (2003) carried out an investigation to identify the determinants of organizational commitment and its factors within the firm. They reported that organizational commitment can be determined by job characteristics such as the job scope and work experiences such as rewards and employee importance. They also suggested that organizational commitment was positively associated with employee performance.

Organizational commitment is one of the most widely researched areas in the field of management in association with various job-related variables in the world but there are few related studies in Iran. Different studies have identified factors influence organizational commitment among employees but the present study concentrates more on the effect of job involvement on organizational commitment. Organizational commitment is one of the most important and crucial outcome of human resource strategies and employee commitment is the key factor in reaching competitive performance (Sahnawaz \& Juyal, 2006). A meaningful relationship is identified between job satisfaction and organizational commitment (Narimawati, 2007). Samad (2007) attempted to detect the effect of job satisfaction on organizational commitment.

According to Kananga (1982) job involvement as a cognitive or belief state of psychological identification with one's job. In other words, this method recommended that an individual's psychological identification with a particular job depends on the saliency of his/ her needs and the perceptions he/she had about the need satisfying potentialities of the job (Kanungo, 1982). Brown (1996) criticized that job involvement would be in the highest level when the work environment makes one believe that one's work is helpful; offers control over how work is taken place; keeps a clear set of behavioral norms; creates feedback concerning completed work available; and provides supportive relationships with supervisors and co-workers. Many other works have investigated that highly involved employees perform substantial efforts towards the achievement of organizational objectives and would less likely to turnover.

Argyris (1957) and McGregor (1960) considered job involvement as a method for aiding productivity and for creating better integration of individual and organizational goals. Marcson (1960) presented an argument and his findings recommended that one of the best ways to increase productivity in organizations was to incorporate employees with jobs, which were more demanding and challenging. Recent studies of job involvement have demonstrated that such involvement enhances the individual's satisfaction, while at the same time, and increases productivity for the organization (Hall \& Lawler, 2000).

This purpose of this study is to investigate the relationship between job involvements on one hand and organizational commitment on the other hand. The independent variable is job involvement whereas organizational commitment is the dependent variable. Recent research findings recommend that a positive and significant relationship exists between job involvement and job satisfaction on the one hand and organizational commitment on the other (Sahnawaz \& Juyal, 2006). These authors further contend that, although both independent variables are strongly associated with organizational commitment, the effect of job satisfaction on organizational commitment is relatively stronger than job involvement is. The focus of this study is to investigate this further.

The primary aim of this study was to investigate the relationship between job involvements on organizational commitment and lower-level employees at Iran. This company was used as a representative of the automaker industry in the province.

This study seeks to answer the following question:

o Is there an association between job involvement and organizational commitment?

Establishing a link between job involvement, on the one hand, and organizational commitment, on the other, could benefit organizations, significantly. Managers are, therefore, able to use human 
resources practices, which increase the levels of job involvement among employees and hence influence positively on their commitment to the organization. The results of this study will demonstrate whether job satisfaction and job involvement have any effect on organizational commitment. If so, future managers would realize how to improve organizational commitment and job involvement.

According to Robbibs (2005), job involvement may result in positive outcomes in organizations such as low absentee levels and higher productivity rates among employees. This study aims to determine the relationship between job involvement and organizational commitment on the other hand. Organizational commitment plays important role for organizational success. Koys (2001) emphasized the significance of organizational commitment for the survival of many organizations. It maximizes the efficiency and the productivity of both the employees and the organization, which ultimately contribute to the effective functioning of organizations.

\section{Methodology}

According to Sekaran (2003), the population of a study is the entire group of people, events, or things of interest that the researchers intend to investigate and it must include the sample to be studied. The population involved in this study was made of people with lower-level employees of auto-maker firms as represented by Iran Khodro. The population for the research included about 1000 employees from the total population $10 \%$ of the lower-level employees were used as a sample. Their job titles included: assemblers, material handlers, inspectors, machine-operators, coordinators and drivers.

Gray (2004) defined a sample as a set of objects, occurrences or individuals selected from a parent population for the purpose of research study. The selected sample was a fairly large portion of the non-managerial employees and was thus fairly well representative of the population. The technique implemented to collect the sample in this study was the stratified probability sampling technique. A sample of 100 lower-level employees of Iran Khodro has been selected based on random sampling technique. Random sampling is a probability sampling technique, whereby each element in the population contains some known chance or probability of being selected as a subject (Uma, 2003).

In this study employees were divided according to their work stations, for instance work station 1,2 , 3 , 4, etc. where each work station represented a stratum. To ensure that samples adequately represented the relevant strata (work stations), respondents were randomly selected from within strata, that is, from each work station using a table of random numbers. The sampling procedure for the research began with a preliminary compilation of a sampling frame. A sampling frame is "a complete list in which each unit of analysis is mentioned only once". As stated before, a table of random numbers was applied to ensure that the sample was representative of the sample frame. The research site was visited for data collection.

\section{Research instruments}

A four-part questionnaire was designed to gather the necessary data. Nachmias and Nachmias (1996) introduced a questionnaire as a list of questions presumably formulated, constructed and sequenced to produce the most constructive data in the most effective manner. The questionnaire consisted of the following four parts:

The first part tapped data associated with biographical and occupational variables including age, gender, marital status, educational qualifications, position held in the organization, and tenure. This data was tapped with a view to obtaining a clear understanding of the sample used in the study. 


\subsection{Kanungo's (1982) job involvement scale (JIS)}

The second part of the questionnaire consisted of Kanungo's (1982) 10-item job involvement scale. This scale measures job involvement on a five-point Likert scale with responses ranging from "Strongly disagree" (1) to "Strongly agree”(5). Kanungo (1982) found this scale to have a Cronbach Alpha coefficient of 0.81 , which indicates a reasonably high level of internal consistency, and therefore a reasonably high level of reliability and construct validity.

\subsection{Mowday et al.'s Organizational Commitment Questionnaire}

The third part of the questionnaire was adopted from Mowday et al. (1979). It is a 15-item questionnaire, which measures organizational commitment, using a five-point Likert scale ranging from "Strongly disagree" (1) to "Strongly agree" (5). This instrument has been examined with several groups such as public employees and university employees. Such tests have yielded reliability coefficients ranging from 0.82 to 0.93 with a median value of 0.90 (Reyes \& Pounder, 1993).

\subsection{Methods of Analysis}

In analyzing the data collected, graphs were implemented to describe the data. In addition, descriptive statistics, Pearson Correlation and Multiple Regression Analysis were employed to analyze the collected data.

\subsection{Descriptive statistics}

Descriptive statistics describe the phenomena of interest (Sekaran, 2003). They include the analysis of data using frequencies, dispersions of dependent and independent variables and measures of central tendency and variability and to obtain a feel for the data (Sekaran, 2003). The mean and standard deviation was primarily be used to describe the data obtained from the JIQ and the OCQ.

\section{Results}

\subsection{Descriptive statistics}

The descriptive statistics in terms of means and standard deviations were measured for Kanungo's Job Involvement questionnaire (1982) and Mowday et al.’s (1979) Organizational Commitment Questionnaire. Table 1 shows the number of cases (sample size) that responded to each questionnaire. Table 1 shows the level of organizational commitment and job involvement for the sample of 100 lower level employees of the company.

\section{Table 1}

Mean, standard deviation and total number of cases in relation to organizational commitment and job involvement

\begin{tabular}{llll}
\hline & Mean & Std. Deviation & $\mathrm{N}$ \\
\hline Organizational commitment & 51.29 & 11.217 & 100 \\
Job involvement & 33.92 & 7.519 & 100 \\
\hline
\end{tabular}

The results indicate that organizational commitment has a mean of 51.29 and a standard deviation of 11.217. The results also indicate that job involvement has a mean of 33.92 and a standard deviation of 7.519. 


\subsection{Hypothesis testing}

This study sought to investigate the relationship between job involvement and organizational commitment. It also sought to determine the relative strength of the association of each of the two independent variable (job involvement), on the one hand, with organizational commitment, as a dependent variable, on the other. To measure job involvement, Kanungo's (1982) 10-item five-point Likert-type rating scale was used. To measure organizational commitment, Mowday et al. (1979) 15item five-point Likert-type rating scale was implemented. Data analysis was performed by means of the Pearson Product Moment Correlation Technique, and Multiple Regression Analysis.

Table 2

Pearson inter-correlations of job involvement and organizational commitment

\begin{tabular}{lcc}
\hline & Organizational commitment & Job involvement \\
\hline Organizational commitment & --- & $.53^{* *}$ \\
Job involvement & $.53^{* *}$ & --- \\
\hline$*_{n}=100 \quad$ ** Significant to 0.01 & &
\end{tabular}

\subsection{Research Hypothesis}

The research hypothesis of the study $\left(\mathrm{H}_{0}\right)$ was stated as, "there is no significant positive correlation between job involvement and organizational commitment" and the corresponding alternative hypothesis $\left(\mathrm{H}_{1}\right)$ was that, "there is a significant positive correlation between job involvement and organizational commitment”. This hypothesis was tested by means of the Pearson Product Moment Correlation technique. The correlation coefficient between job involvement and organizational commitment was found to be $r=0.53$; $p<0.001$. This shows that there was a significant positive association between job involvement and organizational commitment. This leads to a rejection of the null hypothesis and acceptance of the alternative hypothesis. The fact that all the subcategories of overall organizational commitment (Loyalty, Value and Effort) are highly inter-correlated (see Table 2) suggests that job involvement is highly correlated with each of these.

\section{Discussion and Conclusion}

The research hypothesis of the study $\left(\mathrm{H}_{0}\right)$ was stated as: "there is no significant positive correlation between job involvement and organizational commitment," and the corresponding alternative hypothesis $\left(\mathrm{H}_{1}\right)$ was that: "there is a significant positive correlation between job involvement and organizational commitment". This hypothesis was tested by means of the Pearson Product Moment Correlation technique. The correlation coefficient between job involvement and organizational commitment was found to be significant and positively correlated. This leads to a rejection of the null hypothesis and acceptance of the alternative hypothesis.

The findings of the present study have suggested that job involvement was an important factor whose presence in an organization must be ensured. The following studies are in support of the significant positive correlation between job involvement and organizational commitment found in the present study: Moynihan and Pandey (2007) investigated the relationship between job involvement and organizational commitment using a sample of public sector health and human services managers. The study showed that there was a moderately positive correlation between job involvement and organizational commitment. This concurs with the results of the current study.

The organizational commitment meta-analysis conducted by Mathieu and Zajac (1990) also disclosed that among the factors of commitment, the job involvement and organizational commitment relationship were frequently investigated. The two variables were considered to study the impact of some forms of work-related behavior independently. O’Reilly and Chatman (1986) reported that job involvement is an outcome of psychological commitment to an organization. Uygur and Kilic (2009) 
studied the level of organizational commitment and job involvement of the personnel at Central Organizational, Ministry of Health in Turkey. Questionnaires were distributed to a total of 210 subjects. Of this number, 180 (86\%) returned the questionnaire and of these, 168 were found to be useable. A significant positive correlation was found between organizational commitment and job involvement $(r=0.44, p<0.001)$.

There have been many other studies into organizational commitment and job involvement especially associated with the healthcare workers and nurses (Brewer \& Lok, 1995; Brooks \& Swails, 2000; Ors et al., 2003; Sjoberg \& Sverke, 2000; Blau \& Boal, 1989). In a study conducted by Sjoberg and Sverke in a Swedish Emergency Hospital (2000), it was reported that organizational commitment and job involvement were significantly positively correlated. Blau and Boal (1989) found that nurses with a higher level of job involvement and organizational commitment had significantly less unexcused absences than nurses with lower levels of job involvement and organizational commitment did.

One of the significance of the present study is that it was conducted in a developing country, unlike most similar studies that have traditionally been conducted in the highly industrialized countries of the Western world. The present study showed that there was a significant and positive correlation between job involvement and organizational commitment. This concurred with various previous studies conducted as mentioned earlier on. One significant difference between the present study and previous studies is that, the present study was conducted in a various geographical area.

The present study demonstrated that job involvement has a great power to impact organizational commitment therefore the results tell us that companies must pay more attention to promote job involvement in order to ensure higher levels of organizational commitment. The aim of this research was primarily to determine the relationship between job involvement and organizational commitment on the other among lower-level employees in the automaker industry. The results indicate that there was a statistically significant relationship between the independent variable, that is, job involvement and the dependent variable, that is, organizational commitment, on the other.

\section{References}

Argyris, C. (1957). Personality and Organization. New York: Harper Collins.

Blau, G., \& Boal, K. B. (1989). Using job involvement and organisational commitment interactively to predict turnover. Journal of Management, 15 (1), 115-127.

Brewer, A. M., \& Lok, P. (1995). Managerial Strategy and Nursing Commitment in Australian Hospitals. Journal Advanced Nursing, 21, 769-799.

Brooks, I., \& Swailes, S. (2002). Analysis of the relationship between nurse influences over flexible working and commitment to nursing. Journal of Advanced Nursing, 38 (2), 117-126.

Brown, S. P. (1996). A meta-analysis and review of organizational research on job involvement. Psychology Bulletin, 120, 235-255.

Gray, D. E. (2004). Doing research in the real world. London: Sage Publications limited.

Gunlu, E., Aksarayli, M. \& Percin, N. S. (2010). Job satisfaction and organisational commitment of hotel managers in Turkey. International Journal of Contemporary Hospitality Management, 22 (5), 693-717.

Ha-Young, H. (2009). Analysis the factors impact on the Job Involvement and Organisational commitment. Department of Public Administration Korea University

Hall, D. T. \& Lawler, E. E. (2000). Job characteristics and job pressures and the organizational integration of professionals. Administrative Science Quarterly, 15, 271-281.

Hisrchfeld, R. R. \& Field, H. S. (2000). Work centrality and work alienation: Distinct aspects. Of a general commitment to work. Journal of Organisational Behavior, 21(7), pp.789-800.

Hufnagel, E. M. \& Conca, C. (1994). User Response Data: The Potential for Errors and Bias . Information Systems Research, 5, 48-73. 
Kanungo, R. N. (1982). Measurement of Job and Work Involvement. Journal of Applied Psychology, 67(3), 341-349.

Koys, L. (2001). The effects of employee satisfaction, organisational citizenship behaviour, \& turnover on organisational effectiveness: A unit level, longitudinal study, Personnel Psychology, 54(1), 101-114

Marcson, S. (1960). The scientist in American industry. New York: Harper.

Martin, C. L., \& Bennett, N. (1996). The role of justice judgments in explaining the relationship between job satisfaction and organisational commitment. Group \& Organisation Management, 21(1) 84-105.

Maslow, A. (1954). Motivation and Personality; New York: Harper.

Mathieu, J. E. \& Zajac, D. M. (1990). A review and Meta analysis of the antecedents correlates and consequences of organisational commitment. Psychological Bulletin, 108, 171-199.

Maxwell, G. \& Steele, G. (2003). Organisational commitment: a study of managers in hotels. International Journal of Contemporary Hospitality Management, 15(7), 362-369.

McGregor, D. (1960). The Human Side of Enterprise. New York: McGraw-Hill Book Co., Inc.

Mowday, R., Porter, L., \& Steers, R. (1982). Employee organisational linkages- The psychology of commitment, absenteeism and turnover. London: Academic Press.

Moynihan, D. P and Pandey, S. K. (2007). Finding workable levers over work motivation: Comparing job satisfaction, job involvement and organizational commitment. Administration \& Society, 39 (7), 803-832.

Nachmias, C. F., \& Nachmias, D. (1997). Research Methods in Social Sciences. London: ST Martin’s Press Inc.

Organ, D. W, Podsakoff, M. P \& McKenzie, S. B. (2005). Organizational citizenship behaviour, its nature, antecedents and consequences. London: Sage Publications.

O’Reilly, C. A \& Chatman, J. (1986). Organizational commitment and psychological attachment: the effects of compliance, identification and internalization on pro-social behaviour. Journal of Applied Psychology, 71 (3), 492-499.

Örs, M., Acuner, A. M., Sarp, N., \& Önder, Ö. R. (2003). Antalya Tıp Fakültesi Hastanesi’nde, Antalya Sosyal Sigortalar Kurumu Hastanesi'nde ve Antalya Devlet Hastanesi'nde çalısan hekimler ile hemsirelerin örgütlerine baglılıklarına iliskin görüslerinin degerlendirilmesi. Ankara Üniversitesi Tıp Fakültesi Mecmuası, 56(4), 217-224.

Reese H. W, \& Fremour W. J. (1984). Normal and normative ethics in behavioral sciences, American Psychologist, 39(8), 863-876.

Robbins, S. P. (2005). Essentials of Organizational Behaviour. New Jersey: Pearson.

Robert, L. (1997). Human Resources Management. London: West Publishing Company.

Samad, S. (2007). Assessing the effects of job satisfaction and psychological contract on organisational commitment among employees in Malaysian SMEs. The $4^{\text {th }}$ SMEs IN A Global Economy Conference 2007.

Sahnawaz, M. G., \& Juyal, R. C. (2006). Human resources management practices and organisational commitment in different organisations. Journal of the Indian Academy of Applied Psychology, 32, 171-178.

Sekaran, U. (2003). Research methods for business: A skill-building approach. $3^{\text {rd }}$ ed., New York: John Wiley \& Sons, Inc.

Sjoberg, A., \& Sverke, M. (2000). The interactive effect of job involvement and organisational commitment on job turnover revisited: A note on the mediating role of turnover intention. Scandinavian Journal of Psychology, 41, 247-252.

Uygur, A., \& Kilic, G. (2009). A study into Organizational Commitment and Job Involvement: An Application towards the personnel in the central organisation for ministry of health in Turkey. Ozean journal of applied sciences, 2(1).2009.

Wagner, J. A. III, \& Hollenbeck, J. R. (1998). Organizational behavior: Securing competitive advantage, $3^{\text {rd }}$. ed. Upper Saddle River, NJ: Prentice Hall. 
Werner, A. (2007). Organizational Behaviors: A Contemporary South African Perspective. Pretoria: Van Schaik Publishers.

www.thefinancialgazate.co.zw accessed May 2010. www.wikipedia.com accessed May 2010. 